九州大学学術情報リポジトリ

Kyushu University Institutional Repository

\title{
Observed Diverse Indoor Thermal Environments of Low-cost Dwellings Located in a Kampung District
}

Murtyas, Solli

Interdisciplinary Graduate School of Engineering Sciences, Kyushu University

Hagishima, Aya

Interdisciplinary Graduate School of Engineering Sciences, Kyushu University

Kusumaningdyah N.H

Architecture Department, Faculty of Engineering, Universitas Sebelas Maret

https://doi.org/10.5109/4372283

出版情報：Evergreen. 8 (1)，pp.229-238，2021-03. 九州大学グリーンテクノロジー研究教育センター バージョン：

権利関係 : 


\title{
Observed Diverse Indoor Thermal Environments of Low-cost Dwellings Located in a Kampung District
}

\author{
Solli Murtyas ${ }^{1 *}$, Aya Hagishima ${ }^{2}$, Kusumaningdyah N.H \\ ${ }^{1,2}$ Interdisciplinary Graduate School of Engineering Sciences, Kyushu University, Japan \\ ${ }^{3}$ Architecture Department, Faculty of Engineering, Universitas Sebelas Maret, Indonesia
}

*Corresponding Author's email: murtyas.solli.438@s.kyushu-u.ac.jp

(Received December 3, 2020; Revised March 24, 2021; accepted March 26, 2021).

\begin{abstract}
Kampung originally recognized as "village" in the Indonesian language, currently indicates a densely populated urban residential area where many migrants from rural areas reside. Because of the lack of urban infrastructures, poverty, and low-quality houses, people in Kampung districts are vulnerable against various health risks. The purpose of this study is to capture the current indoor thermal environment and thermal characteristics of building envelopes of low-cost dwellings in a Kampung, and to present affordable countermeasures against future climate change. Under these circumstances, a field measurement and survey were conducted in the Pasar Kliwon district, Surakarta City, by an interdisciplinary team aiming to comprehensively understand the urban and architectural conditions. In this project, the room air temperature and relative humidity of 16 dwellings were measured every 10 minutes within one week of the summer period (from the 1 st to the 7th of April 2019). As a result, the observed room air temperatures have demonstrated significant differences ranged from 28.7 to $33.2^{\circ} \mathrm{C}$ among dwellings owing to the diverse design, materials, and quality of buildings. The estimated thermal comfort indices based on the observation data suggest a high ratio from $23 \%$ to $30 \%$ temperature reached more than $30^{\circ} \mathrm{C}$ of the total measured hours and it is evaluated as a time of thermal discomfort. Hence, there arises a necessity to improve the thermal shelter function of the envelopes.
\end{abstract}

Keywords: Kampung district; Indoor environmental quality; Thermal comfort; Temperature; Building envelope

\section{Introduction}

The economic growth in developing countries proceeds with simultaneously massive and rapid urbanization caused by numerous migrants from rural areas seeking a better job and life ${ }^{1)}$. Nevertheless, it is generally difficult for migrants to secure a suitable income and living space. Thus, they inevitably live in low quality dwellings, which are located at informal districts and are in vulnerable condition ${ }^{2}$. In 2006, UN Habitat reported that Asia had the highest number of slum population (581 million) followed by sub-Saharan Africa (199 million) and Latin America-Caribbean (134 million). It indicated that $13.8 \%$ of the world's population was living in slums or informal settlements ${ }^{3)}$. In such informal settlements in developing countries, the lack of urban infrastructure, low quality of houses, and poverty, are serious common issues $^{4)}$. Thus, the residents of these areas are exposed to various health risks ${ }^{5}$.

Indonesia is an emerging country located in South Asia with a population of 200 million, and it has achieved continuous economic growth for decades ${ }^{6}$. Even though the GDP per capita of Indonesia has been ranked as $11^{\text {th }}$ in the world in 2019, the fact that informal urban settlements can be found in most major cities is still a pressing social issue $^{7}$. A district of informal urban settlements in Indonesia is commonly called Kampung, which in Indonesian means "village", and originally described a smallest unit of administrative district in Indonesia ${ }^{8)}$. Kampung currently indicates a densely populated urban residential area where many migrants from rural areas reside. Thus, Kampung is often associated to informal urban settlements, however it is not equivalent to "slum" settlements ${ }^{9)}$.

The unique features of Kampung have attracted the attention of researchers in social sciences and the humanities. Sastrosasmito et al. (2009), based on a field survey and interview of a group of residents in Kampungs in Yogyakarta ${ }^{10)}$, pointed out that people have their own sociological structure and values, and every neighborhood has a particular sense of togetherness and cooperation, called neighbor's kinship. Based on a field survey in the Bustaman village town of Semarang ${ }^{11)}$, Sudarwanto et al. (2018) also reported that such social value can power the community to sustain itself, beyond the lack of adequate basic services and the low quality environment. In addition, several studies on the urban design of Kampungs have been also conducted. For example, Setiawan (1998) investigated how the residents of Kampungs located in Yogyakarta improved and defended their settlements, and 


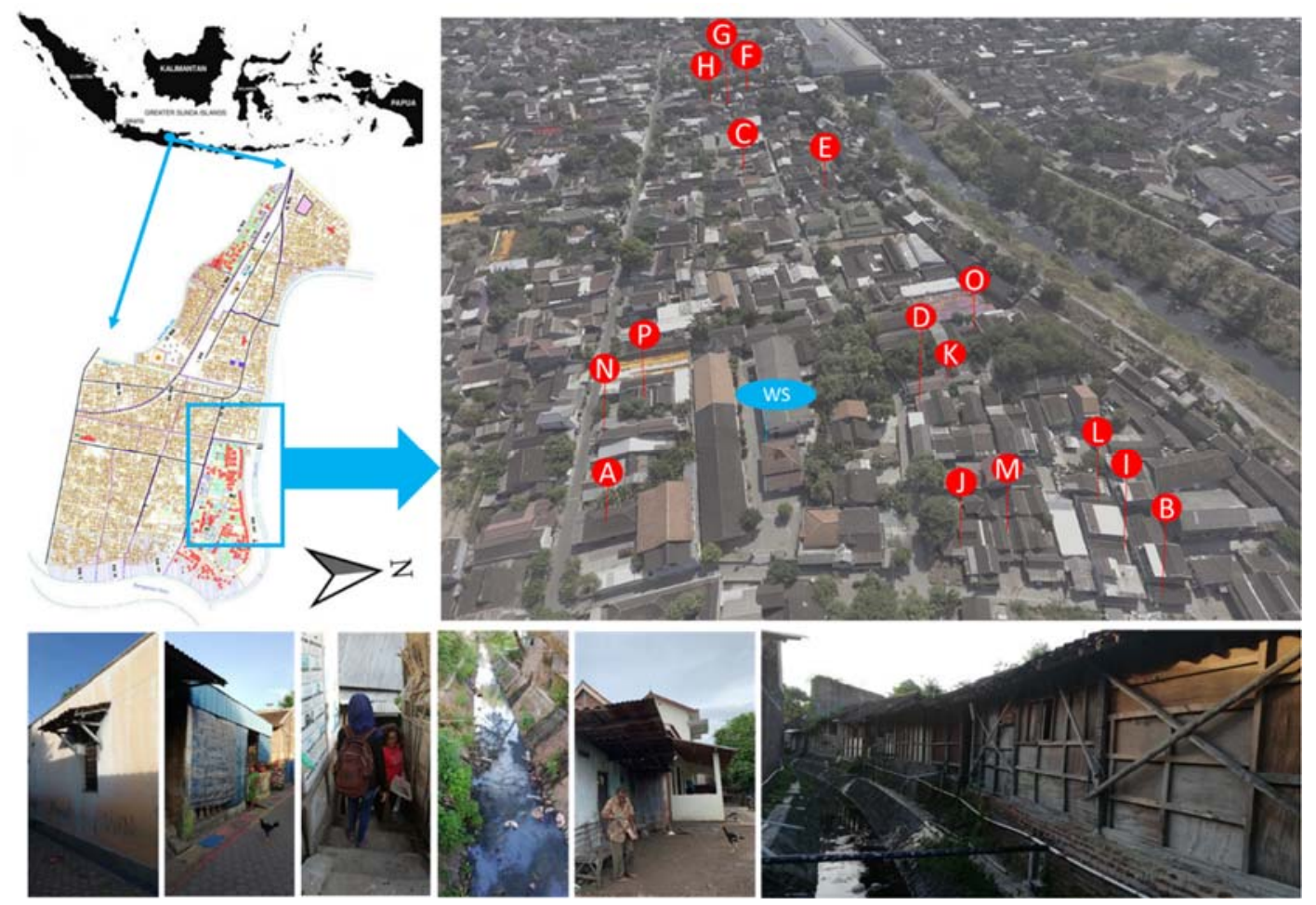

Fig.1: Kampung Sangkrah, Pasar Kliwon District, Surakarta City, Indonesia ${ }^{13)}$ (red and blue marks on aerial photo show the location of thermal sensors and weather station respectively)

pointed out the unique characteristics of informal creative activities, social interaction and the properties that can be shared with the other people ${ }^{12)}$.

However, few studies have aimed to quantitatively capture the physical living quality in Kampungs based on engineering approaches. Kampungs become particularly vulnerable to extreme heat which is associated with global warming due to the lack of a healthy environment and low-quality housing ${ }^{13)}$. In order to improve the current living standard and reduce various health risks of the residents, it is important to grasp the reality of the indoor environment and its underlying mechanisms, and present affordable solutions related to the thermal indoor environment ${ }^{14)}$.

Given this background, this study aims to observe the current indoor thermal environment and thermal characteristics of building envelopes of low-cost dwellings in Kampung, and to present affordable countermeasures against potential heat risks due to future climate change. Under these circumstances, a field measurement and a questionnaire survey have been conducted in Surakarta City, Indonesia, by an interdisciplinary team aiming to comprehensively understand the urban and architectural conditions.

\section{Target District}

Sangkrah, located at the Pasar Kliwon district, Surakarta City, Central Java Province, Indonesia was adopted as a target survey site. It lies at latitude $7^{\circ} 34^{\prime} \mathrm{S}$ and longitude $110^{\circ} 50^{\circ} \mathrm{E}$. Based on the world map of the
Koppen-Geiger climate classification ${ }^{15)}$, Indonesia is categorized as an Af climate zone with fully humid conditions and an equatorial rainforest. This type of climate has a minimum temperature more than $18^{\circ} \mathrm{C}$ and high precipitation with two seasons: dry and wet ${ }^{16)}$. The dry season occurs in the period of May to September when dry air from the southeast (Australia) blows upwards. The wet season starts from December and continues until February, which coincides with summer monsoon in the Southern Hemisphere, where the air mostly blows upwards from the Pacific Ocean. April and October are the transition periods between dry and wet season. The annual mean temperature during the period of 2011 to 2014 was $27.1^{\circ} \mathrm{C}$ and the highest temperature observed in July and August reached up to $34.7{ }^{\circ} \mathrm{C}^{17)}$.

This target district with an area of $4.82 \mathrm{~km}^{2}$ contains large informal settlements. In 2016, the total population of this district was 10,885 people living in 2473 houses. The number of average occupants per house was $3.4^{18)}$. There are two rivers along the border of Sangkrah: Pepe river in the south and Bengawan Solo river in the east. The ratio of poor people is $30 \%$. This was the highest proportion compared with those of other Kampungs of Surakarta City in $2010^{19}$. Note that poor people is are defined as people with income lower than the minimum regional value of the city, which was IDR $1,418,000$ per month per capita 
Table 1. Target of dwellings measurement classified based on building construction

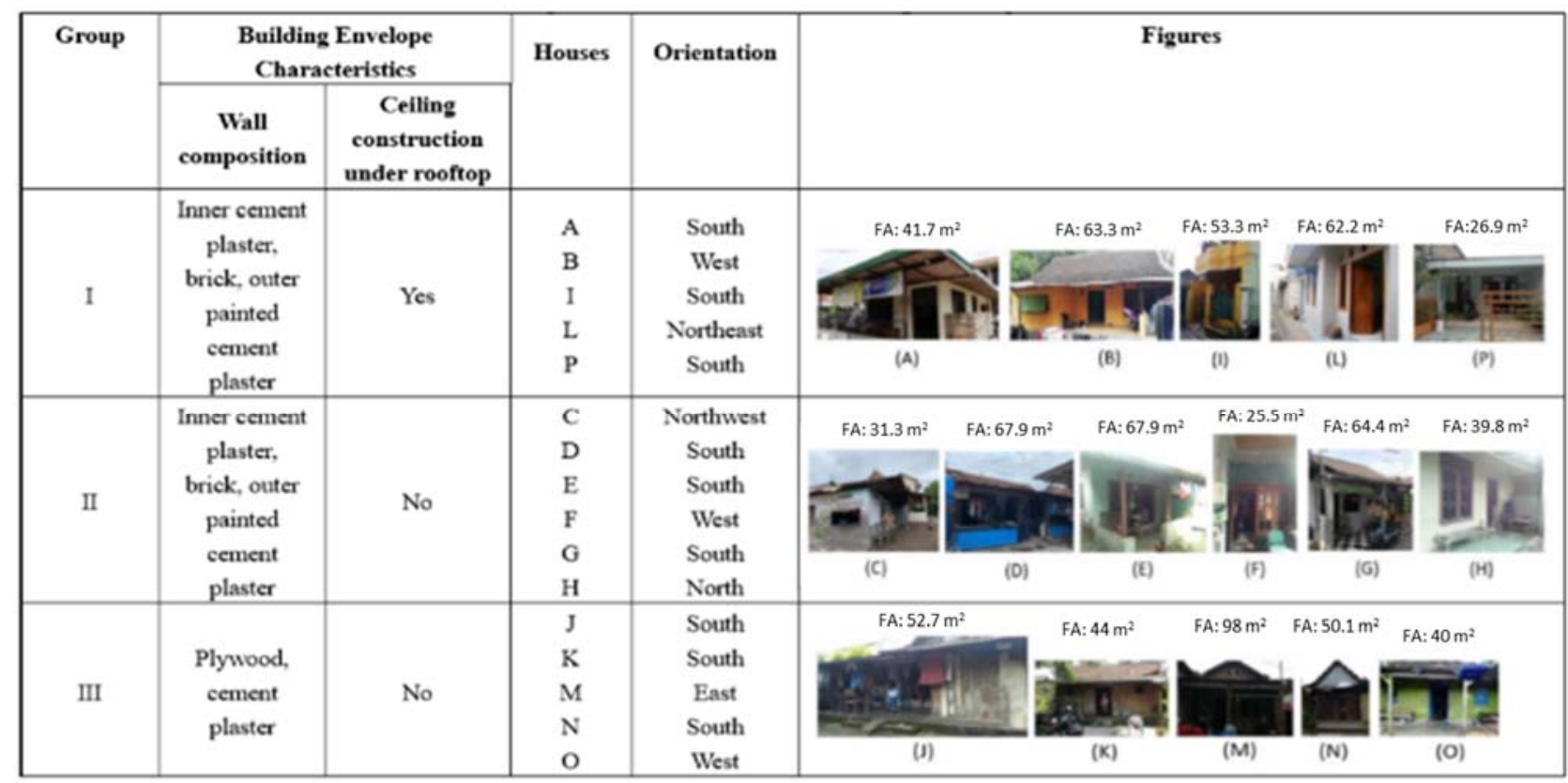

-FA: Floor Area $\left(m^{2}\right)$

(in 2016) $^{20)}$. The SMERU Research Institute reported ${ }^{19)}$ that limited education and skills are the main reasons why people cannot secure jobs with steady and adequate incomes to fulfill their daily necessities. The demography survey conducted by Solo Kota $\mathrm{Kita}^{21}$ ) (an NGO based in Surakarta collaborating with USAID and UN Habitat) indicates that the proportions of residents' occupations in this district are: civil servant 5\%, small trader $25 \%$, laborer $60 \%$, and informal sector $10 \%$.

\section{Methodology}

\subsection{Target dwellings selected for the survey}

A field measurement was conducted from $1^{\text {st }}$ April, 2019 until $26^{\text {th }}$ August, 2019 to observe the diverse indoor thermal environment of the 16 dwellings located in the

Table 2. Technical specifications of measurement instruments

\begin{tabular}{|c|c|c|c|c|}
\hline Parameters & Series & Instruments & Description & Quantity \\
\hline $\begin{array}{l}\text { Outdoor } \\
\text { temperature and } \\
\text { humidity }\end{array}$ & $\begin{array}{l}\text { ONSET S-THB- } \\
\text { M002 }\end{array}$ & $\begin{array}{l}\text { 12-bit } \\
\text { temperature/RH } \\
\text { sensor }\end{array}$ & $\begin{array}{l}\text { Measurement } \\
\text { range }-40 \text { to } 75 \\
{ }^{\circ} \mathrm{C} \text {, accuracy } \pm \\
0.21{ }^{\circ} \mathrm{C} \\
\text { (temperature) and } \\
0-100 \% \text {, accuracy } \\
\pm 2.5 \%(\mathrm{RH})\end{array}$ & 1 \\
\hline Precipitation & $\begin{array}{l}\text { ONSET S-RGF- } \\
\text { M002 }\end{array}$ & $\begin{array}{l}\text { Davis } 0.2 \mathrm{~mm} \text { rain } \\
\text { gauge sensor }\end{array}$ & $\begin{array}{l}\text { Measurement } \\
\text { range } 0 \text { to } 102 \\
\text { mm per hour per } \\
\text { day, accuracy } \\
\pm 4.0 \%\end{array}$ & 1 \\
\hline $\begin{array}{l}\text { Wind velocity and } \\
\text { direction }\end{array}$ & $\begin{array}{l}\text { ONSET S-WCG- } \\
\text { M003 }\end{array}$ & $\begin{array}{l}\text { Ultrasonic wind } \\
\text { speed and } \\
\text { direction sensor }\end{array}$ & $\begin{array}{l}\text { Measurement } \\
\text { range } 0-41.16 \mathrm{~m} / \mathrm{s} \text {, } \\
\text { accuracy } 0.8 \mathrm{~m} / \mathrm{s}\end{array}$ & 1 \\
\hline $\begin{array}{l}\text { Room air } \\
\text { temperature and } \\
\text { humidity }\end{array}$ & T\&D TR-72nw & $\begin{array}{l}\text { Dual channel data } \\
\text { logger and sensor } \\
\text { for temperature } \\
\text { and } \mathrm{RH}\end{array}$ & $\begin{array}{l}\text { Measurement } \\
\text { range } 0 \text { to } 55^{\circ} \mathrm{C} \text {, } \\
\text { accuracy } \pm 0.5{ }^{\circ} \mathrm{C} \\
\text { (temperature) and } \\
10-95 \% \text {, accuracy } \\
\pm 5 \%(\mathrm{RH})\end{array}$ & 16 \\
\hline Solar radiation & $\begin{array}{l}\text { ONSET S-LIB- } \\
\text { M003 }\end{array}$ & $\begin{array}{l}\text { Solar radiation } \\
\text { (silicon } \\
\text { pyranometer) } \\
\text { sensor }\end{array}$ & $\begin{array}{l}\text { Measurement } \\
\text { range } 0 \text { to } 1280 \\
\mathrm{~W} / \mathrm{m}^{2} \text { accuracy } 10 \\
\mathrm{~W} / \mathrm{m}^{2}\end{array}$ & 1 \\
\hline
\end{tabular}

Table 3. Questions on thermal sensation and options shown for answer

\begin{tabular}{|l|r|l|}
\hline \multicolumn{1}{|c|}{ Questions } & \multicolumn{1}{|c|}{ Scales } & Description \\
\hline \multirow{4}{*}{$\begin{array}{l}\text { How are you feeling } \\
\text { now? }\end{array}$} & +3 & Hot \\
\cline { 2 - 3 } & +2 & Warm \\
\cline { 2 - 3 } & +1 & Slightly Warm \\
\cline { 2 - 3 } & 0 & Neutral \\
\cline { 2 - 3 } & -1 & Slightly Cool \\
\cline { 2 - 3 } & -2 & Cool \\
\hline \multirow{4}{*}{$\begin{array}{l}\text { Are you satisfied with } \\
\text { the current thermal } \\
\text { condition? }\end{array}$} & -3 & Cold \\
\cline { 2 - 3 } & +3 & Very Satisfied \\
\cline { 2 - 3 } & +2 & Satisfied \\
\cline { 2 - 3 } & +1 & Slightly Satisfied \\
\cline { 2 - 3 } & -1 & Neutral \\
\cline { 2 - 3 } & -2 & Slightly Dissatisfied \\
\hline \multirow{4}{*}{$\begin{array}{l}\text { What would you prefer } \\
\text { for the thermal } \\
\text { condition? }\end{array}$} & -3 & Very Dissatisfied \\
\cline { 2 - 3 } & +2 & Much Warmer \\
\cline { 2 - 3 } & +1 & Bit Warmer \\
\hline & 0 & No Change \\
\hline & -1 & Bit Cooler \\
\hline
\end{tabular}

target district. In this paper, the results of the field measurements for one week starting on $1^{\text {st }}$ April, 2019 are reported. In addition, a questionnaire survey on the occupants' thermal comfort sensation, thermal adaptive behaviors, and building materials was also conducted from $14^{\text {th }}$ to $31^{\text {st }}$ July, 2019.

Table 1 shows outlines of building conditions of the 16 target dwellings. The location of each dwelling is shown in an aerial photograph (see Fig. 1), for the measurement. 


\section{Wind Speed $(\mathrm{m} / \mathrm{s})$}
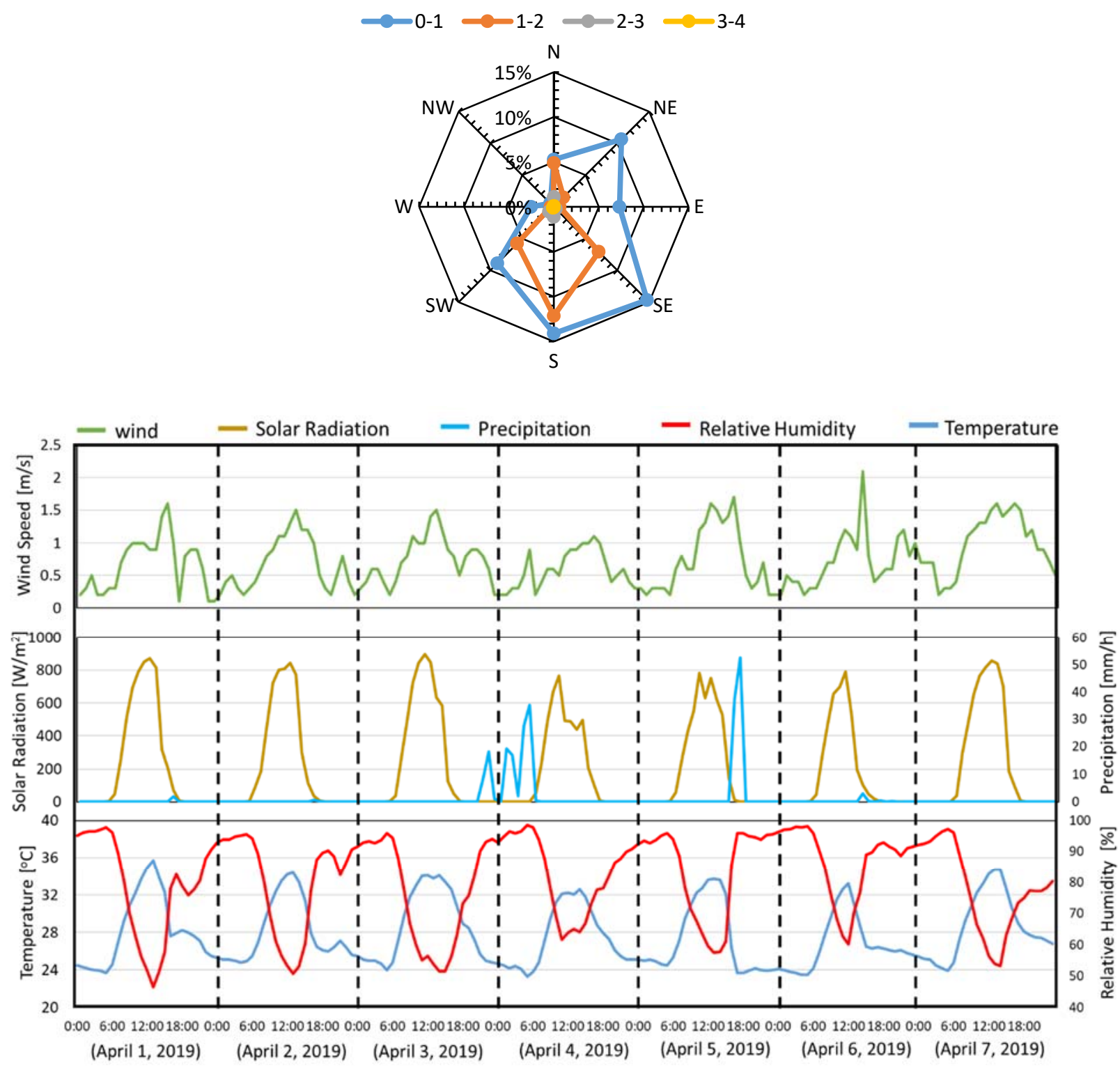

Fig. 2: Weather data measured in the period of April 1-7, 2019

These houses were selected to capture the diversity of living environment ${ }^{22}$ ) by considering the household income, building construction type, and size of buildings with the area from $26 \mathrm{~m}^{2}$ to $105.6 \mathrm{~m}^{2}$.

\subsection{Instrumentation of thermal environment monitoring}

Indoor temperature and humidity were measured every 10 minutes in 16 dwellings. Fourteen sensors were installed in living rooms and 2 sensors were placed in bedrooms. Each sensor was located at a height of $1.5 \mathrm{~m}$ from the floor with a distance of at least $0.5 \mathrm{~m}$ from walls in order to measure the indoor conditions to which occupants are exposed.

In addition, every 1 minute, the outdoor air temperature, relative humidity, global solar radiation, wind velocity, and precipitation were measured at a height of $5 \mathrm{~m}$ from the ground at the open space of Sangkrah elementary school, which is shown in Fig. 1. An ultrasonic anemometer was used to precisely measure very low wind speed considering the dense urban conditions. The measurement items and instruments are shown in Table 2.

\subsection{Questionnaire survey on thermal comfort}

To grasp the occupants' adaptation behaviors and perception of thermal comfort, a questionnaire survey was conducted. 102 respondents were asked to answer the oral questions. Their answers were recorded by interviewers using a tablet.

Table 3 shows main questions related to thermal sensation at the moment when the questionnaire was conducted, which were determined based on the ASHRAE 
Standard 55-2010. As it can be seen from this table, answers related to thermal perception were expressed as a quantitative grading on a 5-point or 7-point scale. The answers to the first question listed in Table 2 are referred to as thermal sensation vote (TSV).

In addition, questions about the demographic information of respondents, such as age, gender, education background, employment, total number of occupants of their dwelling, and daily activities, were adopted.

\section{Results and Discussion}

\subsection{Weather condition}

Fig. 2 shows the time series data of the outdoor air temperature, relative humidity, solar radiation, wind speed, and precipitation. The data of 4 days among the 7 days show an almost symmetric diurnal variation of solar radiation with no precipitation, suggesting clear sky conditions. The daily maximum outdoor temperature of these 4 fine days' ranges from 34 to $36^{\circ} \mathrm{C}$. In contrast, the daily minimum temperature of $24^{\circ} \mathrm{C}$ is exhibited at $5 \mathrm{am}$, which is consistent with the time of sunrise. The time variation of relative humidity is opposite to that of outdoor temperature as expected, and values during night-time exceed $90 \%$ in all 7 days. Wind speed is generally high in daytime and low in night-time, showing a clear diurnal cycle. In addition, the wind direction is most frequently to the south $(27 \%)$ and southeast $(22 \%)$.

Table 4 provides the statistics of outdoor climate variables. The mean outdoor air temperature during the measurement period was $27.9^{\circ} \mathrm{C}$, which is $0.8^{\circ} \mathrm{C}$ higher than the annual average probably due to the dry season. The average wind speed was $0.7 \mathrm{~m} / \mathrm{s}$, which implies the low potential of natural ventilation for passive cooling. The maximum precipitation per hour during the period was $52.4 \mathrm{~mm}$.

\subsection{Indoor thermal comfort}

Table 5 shows statistics of indoor air temperature for each dwelling, which are sorted by the average of the daily amplitudes of temperature. Fig. 3 shows averaged daily variations of the indoor air temperature and those of temperature difference between indoors and outdoors in all dwellings. House L shows the lowest daily change of indoor temperature among the 15 houses, as can be seen in Table 5. This implies that the building envelopes of this house are thermally resilient and can stabilize the

Table 4. Statistics of outdoor weather conditions of the period of 7 days starting on the 1st of April 2019

\begin{tabular}{|l|l|l|l|l|l|}
\hline & $\mathbf{T}\left({ }^{\circ} \mathbf{C}\right)$ & $\mathbf{R H}(\%)$ & $\begin{array}{l}\text { Daily solar } \\
\text { radiation } \\
\left(\mathbf{M J} / \mathbf{m}^{2} \mathbf{d a y}\right)\end{array}$ & $\begin{array}{l}\text { Wind } \\
\text { speed } \\
(\mathbf{m} / \mathbf{s})\end{array}$ & $\begin{array}{l}\text { Rain } \\
(\mathbf{m m} / \mathbf{h})\end{array}$ \\
\hline Mean & 27.9 & 81.1 & 16.5 & 0.7 & 1.3 \\
\hline Std. deviation & 3.5 & 14.8 & 2.9 & 0.4 & 6.4 \\
\hline Minimum & 23.3 & 46.6 & 10.5 & 0.1 & 0 \\
\hline Maximum & 35.7 & 98.5 & 19.7 & 2.1 & 52.4 \\
\hline
\end{tabular}

temperature fluctuations of indoor air. Interestingly, house $\mathrm{O}$ experienced a higher temperature in the sleeping period than the other houses, as can be observed in Fig. 3. In contrast, house $\mathrm{J}$ exhibits the largest daily variation of indoor temperature: $8{ }^{\circ} \mathrm{C}$. This indicates that this house was exposed to a relatively high temperature in the daytime and low temperature in the night time. Regarding the statistics for the active period (10:00 to 16:00) and the sleeping period (22:00 to 5:00), House $G$ exposed the highest mean and maximum temperature during the activity period. In contrast, house $\mathrm{O}$ shows the highest mean and maximum temperature during the sleeping period.

Regarding the diurnal cycle of indoor temperature, it is higher than outdoor temperature during the night-time (17:00 to 7:00) in all dwellings. In contrast, during daytime (9:00 to 16:00), most of the houses have lower interior temperatures than the outdoor temperature. House $\mathrm{G}$ was the only house which experienced higher indoor temperature than outdoor during the daytime. Fig. 3a also shows the delay of the time period of the daily maximum of indoor air temperature compared to that of outdoor
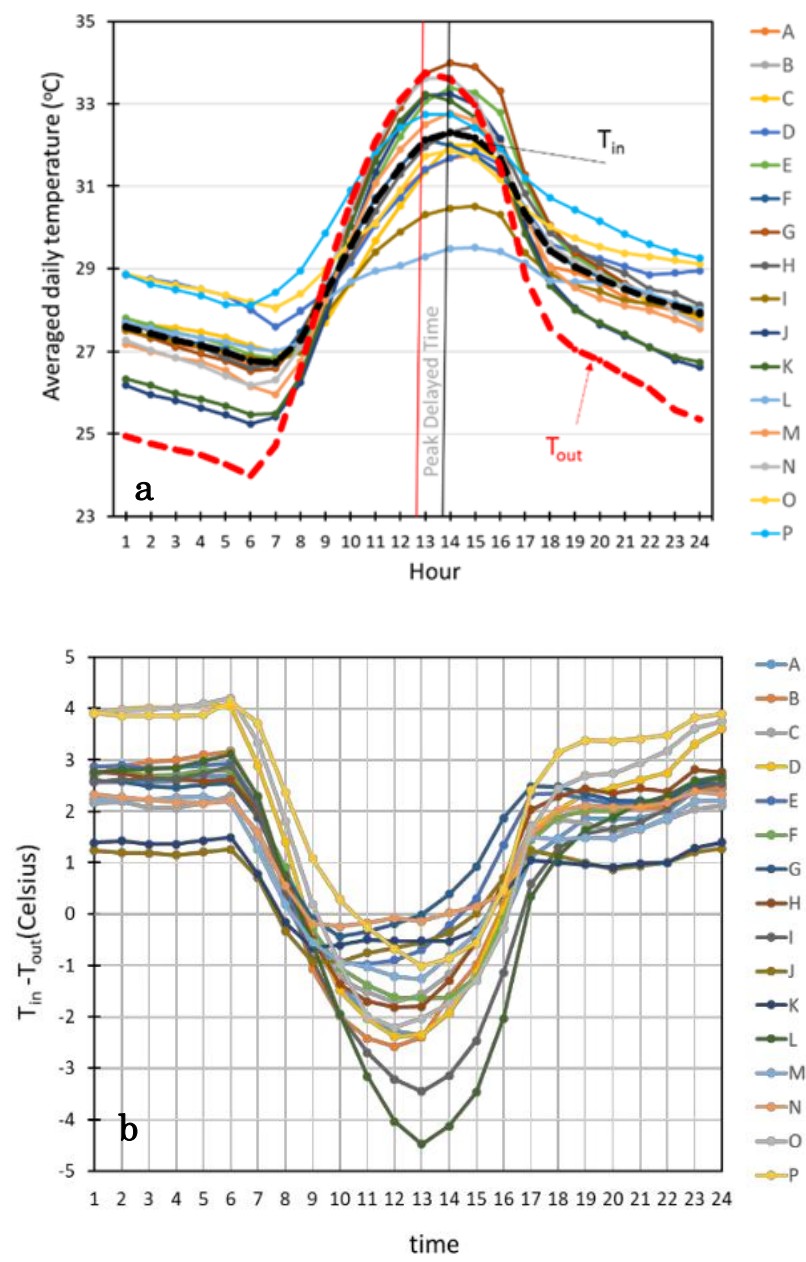

Fig. 3: Averaged daily variation of indoor temperature (a), and difference between indoor-outdoor temperature (b) 

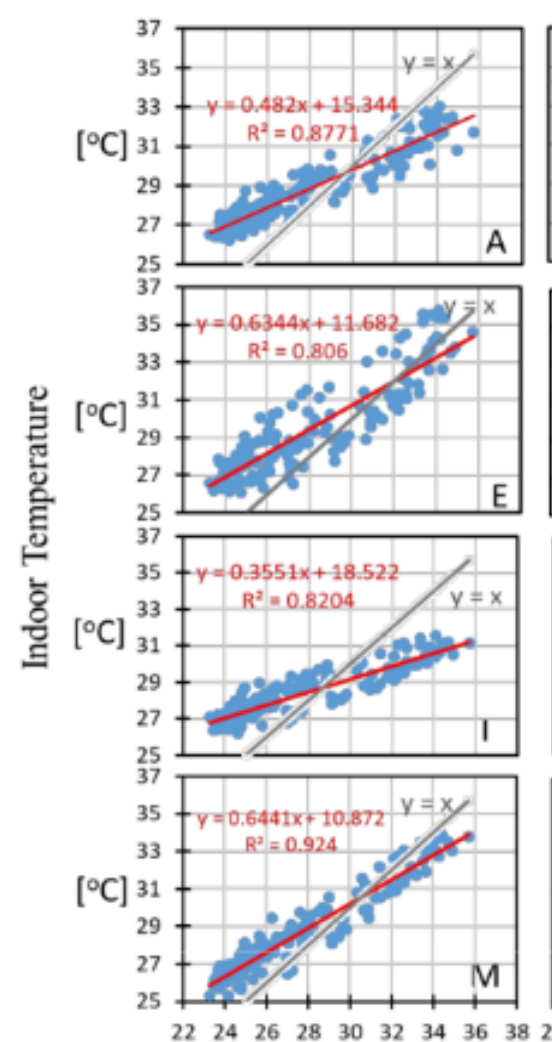

$\left[{ }^{\circ} \mathrm{C}\right]$
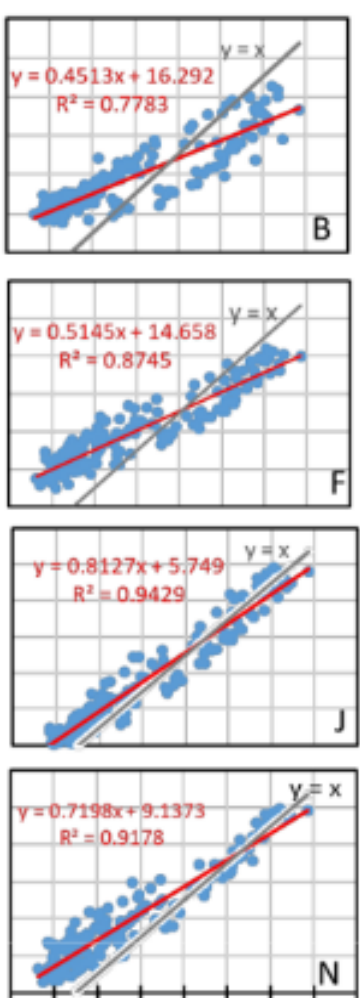

$\mathrm{N}$

$\left[{ }^{\circ} \mathrm{C}\right]$
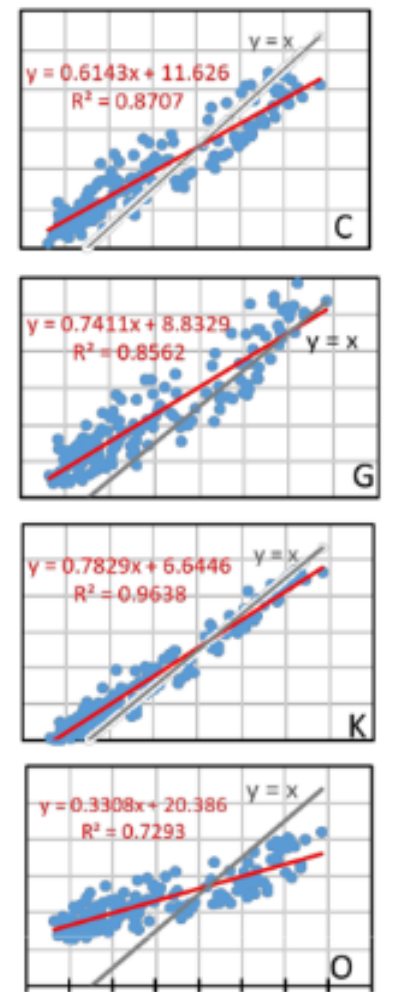

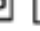
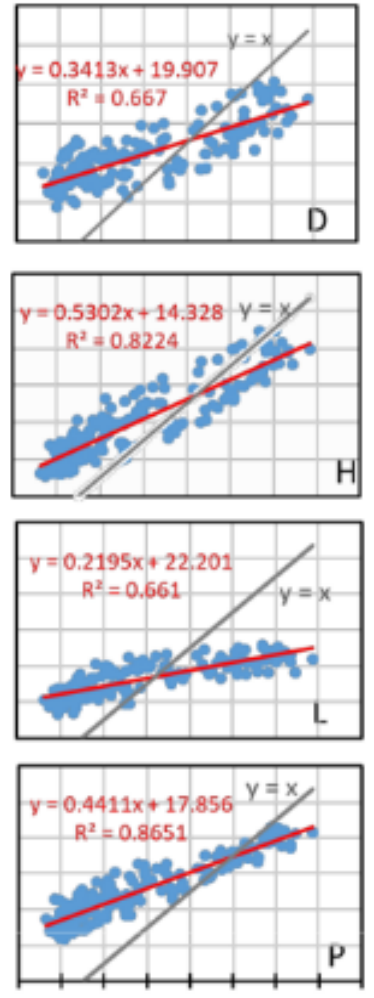

$\left[{ }^{\circ} \mathrm{C}\right]$

$\left[{ }^{\circ} \mathrm{C}\right]$

Outdoor Temperature

Fig. 4: Linear regression of indoor and outdoor temperature

temperature. The average indoor temperature reached the maximum value at 14:00, that is, later than the outdoor temperature peak time (13:00). Fig. 3b shows house $\mathrm{L}$ had the highest value of temperature difference between indoors and outdoors. This implies that the insulation of house $\mathrm{L}$ was better than that of other houses.

Fig. 4 indicates the linear regression between the indoor and outdoor temperatures of each house. House $\mathrm{J}$ expressed a value of $\mathrm{R}^{2}$ equal to 0.9429 , which is the highest value among the houses observed. Indoor air temperature in house $\mathrm{J}$ was almost similar to the outdoor temperature. By contrast, the indoor temperature of house $\mathrm{L}$, with the smallest $\mathrm{R}^{2}$ value, is less affected by the outdoor temperature. Such a feature implies that the thermal shelter function of house L performed properly. The thermal shelter function of a building has been characterized by the decrement factor $f$ expressed in equation $1^{23)}$.

$$
f=\frac{T_{\text {in_max }}-T_{\text {in_min }}}{T_{\text {out_max }}-T_{\text {out_min }}}
$$

where $f$ is a dimensionless factor which usually ranges from 0 to 1 and describes the amplitude of daily variation of indoor temperature to outdoor temperature. Meanwhile, a gradient coefficient, included in the linear regression between outdoor and indoor temperature shown in Fig. 4, also has a similar physical meaning. Fig. 5 shows the relation between the gradient coefficient and decrement factor. A plot of each dwelling is classified into the groups of building structure type shown in Table 1. All the plots show consistent positive relation, and dwellings categorized as group III have higher values of both gradient and decrement factor. In contrast, dwellings of group I have lower values, and plots of group II are located between the two previous groups.

Table 5. Indoor thermal measurement result (red maximum and blue minimum value)

\begin{tabular}{|c|c|c|c|c|c|}
\hline \multirow{2}{*}{ House } & \multirow{2}{*}{$\begin{array}{c}\text { Mean } \\
\text { Daily } \\
T_{\text {nar- }} \\
T_{x y t}\end{array}$} & \multicolumn{2}{|c|}{$\begin{array}{r}\text { Activity Period } \\
(9: 00 \text { to } 16: 00)\end{array}$} & \multicolumn{2}{|c|}{$\begin{array}{c}\text { Sleeping Period } \\
(22: 00-5: 00)\end{array}$} \\
\hline & & $T_{\operatorname{mix}}$ & $\mathrm{T}_{\max }$ & $T_{\min }$ & $T_{\max }$ \\
\hline L & 2.8 & 28.7 & 29.5 & 27.1 & 28.2 \\
\hline I & 4.1 & 28.7 & 30.5 & 26.9 & 28.0 \\
\hline 0 & 4.1 & 29.7 & 31.9 & 28.2 & 29.3 \\
\hline D & 4.6 & 29.1 & 31.8 & 28.0 & 29.0 \\
\hline$P$ & 4.9 & 30.9 & 32.8 & 28.1 & 29.4 \\
\hline A & 5.5 & 29.3 & 31.8 & 26.7 & 28.0 \\
\hline B & 5.5 & 28.6 & 32.0 & 27.2 & 28.0 \\
\hline F & 5.6 & 29.6 & 32.1 & 26.8 & 28.1 \\
\hline $\mathrm{H}$ & 6.1 & 29.3 & 32.5 & 26.6 & 28.4 \\
\hline C & 6.6 & 29.4 & 32.4 & 26.3 & 27.6 \\
\hline $\mathrm{E}$ & 6.9 & 29.7 & 33.4 & 26.9 & 28.2 \\
\hline $\mathrm{M}$ & 7.1 & 29.7 & 32.8 & 26.2 & 27.8 \\
\hline $\mathrm{N}$ & 7.8 & 30.4 & 33.6 & 26.2 & 28.0 \\
\hline G & 8 & 30.2 & 34 & 26.5 & 28.1 \\
\hline $\mathrm{K}$ & 8.1 & 29.8 & 33.2 & 25.5 & 26.9 \\
\hline $\mathrm{J}$ & 8.4 & 29.7 & 33.2 & 25.2 & 26.8 \\
\hline
\end{tabular}




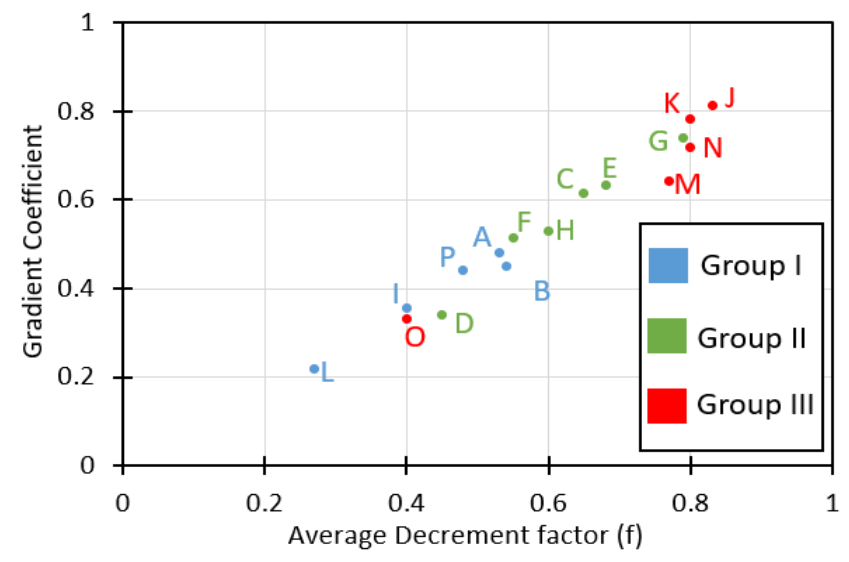

Fig. 5: Scattered plot of decrement factor and gradient coefficient group of houses

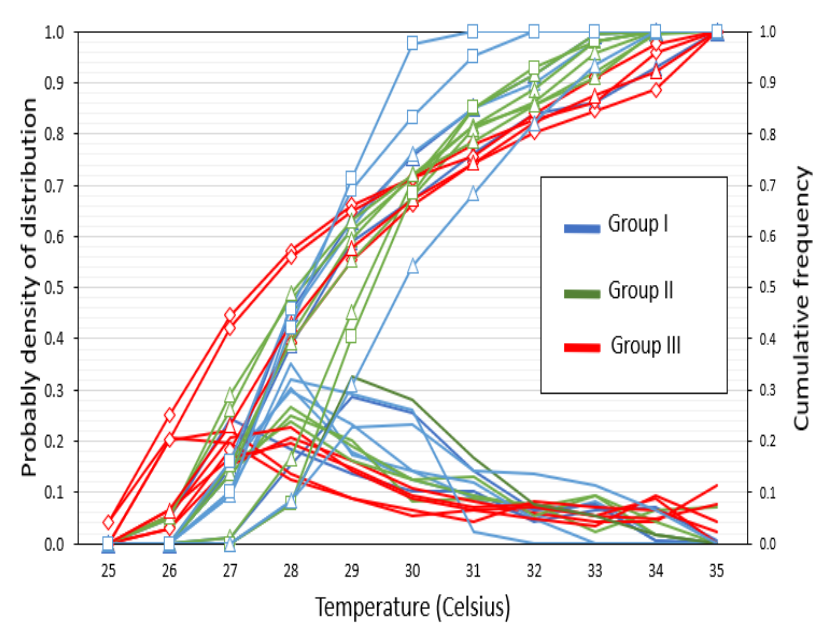

Fig. 6: Probability density distribution and cumulative probability distribution of measured indoor temperature in all the dwellings

Fig. 6 shows the probability density distribution and cumulative probability density distribution of the measured indoor temperature. The probability of time duration when temperature above $30{ }^{\circ} \mathrm{C}$ occurred in houses of group I, II, and III, were $23 \%, 31 \%$, and $30 \%$, respectively. This indicates that group II has the longest time of hot indoor condition among the groups. It is noteworthy that group III shows almost similar time duration of high temperature conditions. Nonetheless, Fig. 5 shows that houses of group III have poor thermal performance in terms of decrement factor and gradient coefficient. This is caused by the fact that weak insulation specifications are advantageous with respect to reducing the indoor air temperature during night-time by utilizing nocturnal radiative cooling and natural ventilation.

Comparing the data of group I and group II with similar type of wall materials, the data of group II dwellings without a ceiling board under the rooftop show longer time duration of hot indoor environment than the others, thus highlighting the importance of ceiling boards.

Table 6. Respondent profiles by group of ages

\begin{tabular}{|c|c|c|}
\hline \multirow{2}{*}{ Age } & \multicolumn{2}{|c|}{ Respondents } \\
\cline { 2 - 3 } & Female & Male \\
\hline $11-20$ & 14 & 2 \\
\hline $21-30$ & 7 & 12 \\
\hline $31-40$ & 17 & 13 \\
\hline $41-50$ & 9 & 10 \\
\hline $51-60$ & 5 & 9 \\
\hline $61-70$ & 3 & 1 \\
\hline Total & 55 & 47 \\
\hline
\end{tabular}

a. TSV and PMV

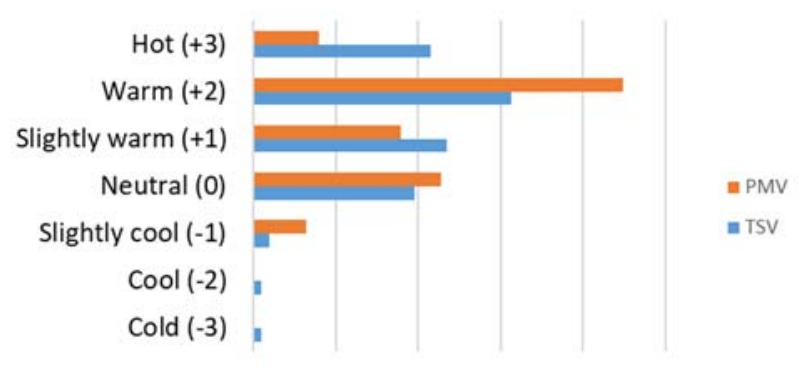

b. Thermal Satisfaction

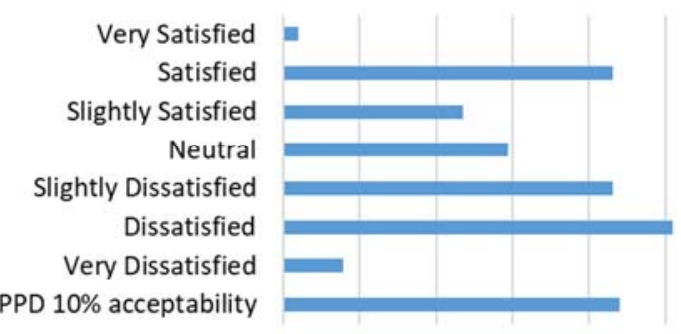

c. Thermal Preference

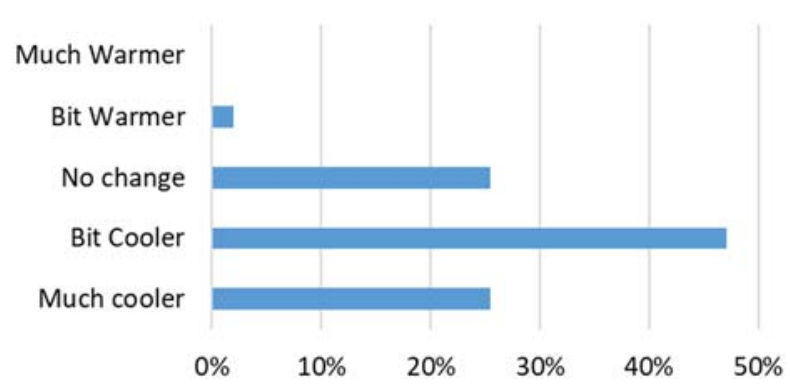

Fig. 7: (a) Distribution of Thermal Sensation Vote (TSV) and Predicted Mean Vote (PMV), (b) Thermal Satisfaction and (c) Thermal Preference

\subsection{Thermal sensation}

Predicted mean vote (PMV) is a numerical estimation method of thermal sensation in a 7 points scale developed by Fanger ${ }^{24}$ based on a heat balance equation of the human body. We calculated PMV values based on the 
observed data during the period of measurement. In Fanger's PMV model, mean radiant temperature is an important variable to calculate PMV values. In this study, we assumed that mean radiant temperature is equal to air temperature ${ }^{25}$. Note that this assumption is applicable when the value of average air speed is below $0.2 \mathrm{~m} / \mathrm{s}$ and the metabolic rate of occupants is between 1 to 2 met (light activities) ${ }^{26)}$. Indoor air speed was assumed to be $0.1 \mathrm{~m} / \mathrm{s}$. The metabolic rate from 6:00 to 21:00, which represents the light activities, and from 22:00 to 5:00, which indicates the sleeping/rest activities, were 1.2 and 0.8 , respectively. In addition, we assumed a clothing insulation value of 0.5 clo.

A questionnaire on the thermal sensation of the occupants of the target 16 houses was conducted. The

a. What do you do to achieve thermal comfort?

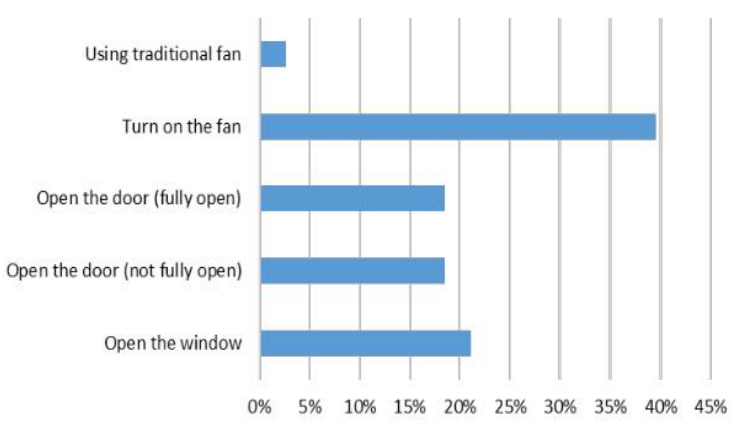

b. What do you usually do in the house (between $10 \mathrm{am}$ to $4 \mathrm{pm})$ ?

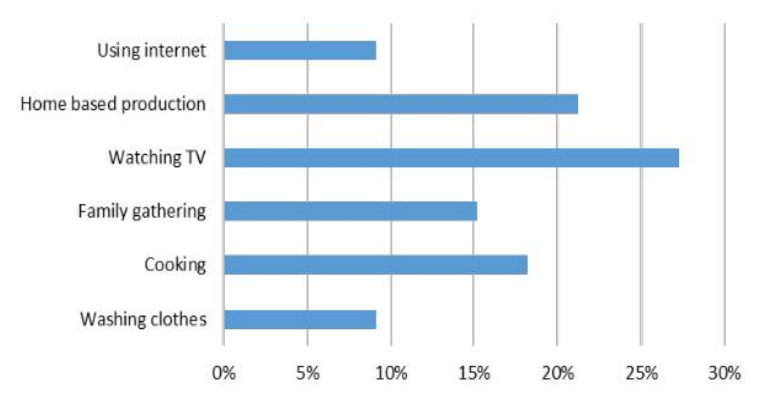

c. When do you usually feel thermal discomfort?

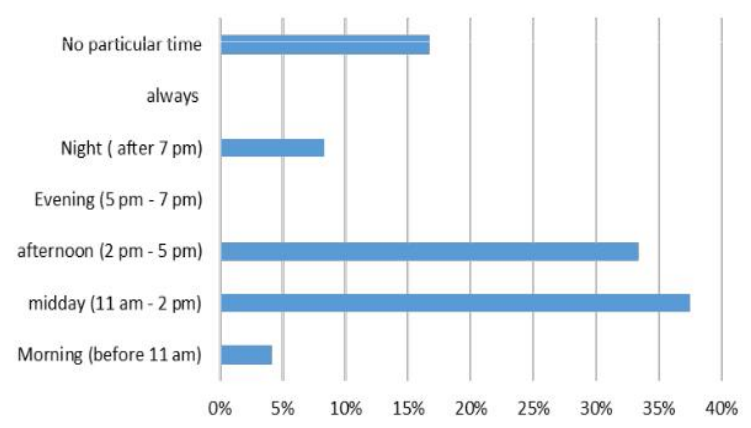

Fig. 8: Distribution of votes correlating to daily activities and thermal adaptive behavior

profile of respondents based on the age and gender is shown in Table 6 . The total number of respondents was 102, including 55 females and 47 males, of ages varying from 11 to 68 years old. Fig. 6 shows the result of thermal sensation votes including the estimated PMV for a comparison. We observe that $31 \%$ of the people stated "warm" in the questionnaire. In addition, slightly warm and hot were also dominant feelings with percentages of $23 \%$ and $22 \%$ respectively. By contrast, the estimated PMV was $45 \%$ for "warm $(+1)$ ". "Slightly warm" and "slightly hot" were estimated by PMV at $18 \%$ and $8 \%$, respectively. This difference indicates that the comfort range of respondents living in the target dwellings represented by TSV is wider than PMV, which is consistent with recent studies on adaptive thermal comfort. It is interesting to note that while most people stated "warm", the percentage of people who were satisfied was relatively high (22\%). However, $26 \%$ of the people were still dissatisfied with the indoor thermal condition. By contrast, the predicted percentage of dissatisfied (PPD) is lesser than $10 \%$, which defined the thermal environment's acceptability adopted from the ANSI/ASHRAE standard $55: 2010^{27)}$, shows a $22 \%$ ratio of time evaluated as thermally comfortable.

According to the thermal adaptive behavior as shown in Fig. 8, people mostly prefer to turn the electricity fan on $(39 \%)$ in order to adjust from a discomfort to a comfort condition. Some of them choose to open the window $(21 \%)$, open the door (fully open $(18 \%)$, not fully open $(18 \%))$. People usually feel discomfort in the midday (11 am to $2 \mathrm{pm}-38 \%$ ) and the afternoon ( $2 \mathrm{pm}$ to $5 \mathrm{pm}-33 \%$ ). Furthermore, $8 \%$ of the people even feel thermal discomfort in the night-time (after $7 \mathrm{pm}$ ). None of them felt thermal discomfort in the evening. Thus, based on this survey, it was concluded that the most comfortable period for the people was in the evening.

\section{Conclusions}

A field measurement of indoor thermal conditions was conducted in 16 low cost dwellings in Sangkrah, a Kampung district in Surakarta City, Central Java Province, Indonesia. The measured results suggested that diverse diurnal variations of indoor temperature occur according to the characteristics of building envelopes. The result also indicated that houses with low thermal insulation performance are not necessarily equal with respect to the houses that have longer time durations of hot indoor conditions. Conversely, houses with a small decrement factor, i.e. relatively high shelter function of building envelopes, exhibit much higher indoor temperature compared to outdoor temperature during night-time owing to the reduced nocturnal radiation cooling and heat storage in the building envelope. The results of a questionnaire survey on the thermal sensation and satisfaction of the residents of the target houses were also reported. The survey indicated that people tend to accept the hot indoor environment, resulting in a higher fraction of satisfaction compared to the estimation of PMV. These findings would contribute to establish strategies to improve thermal comfort, reduce the heat risk, and improve the quality of 
living of people living in low-cost dwellings in Kampung districts in the future.

\section{Acknowledgements}

This study was supported by the Urban-Rural Design and Conservation Laboratory, Department of Architecture, Sebelas Maret University, Indonesia. Thanks to all the members of this lab who strived to provide a conducive research environment especially to the students who accompanied the author conducting the field measurement. This project was also partially funded by the Robert $\mathrm{T}$. Huang Entrepreneurship Center of Kyushu University.

\section{References}

1) J. Scott, "The risk of rapid urbanization in developing countries," Zurich, (2015).

2) I.A.W. Hutama, "Exploring the Sense of Place of an Urban," University of Twente, 2016.

3) N. Bazoglu, T. Chowdhury, and G. Mbpoup, "The State of the World's Cities Report," Sterling, 2006.

4) B. Shahriari, A. Hassanpoor, A. Navehebrahim, and S. Jafarinia, "A systematic review of green human resource management," Evergreen, 6 (2) 177-189 (2019).

5) K. Pantavou, G. Theoharatos, A. Mavrakis, and M. Santamouris, "Evaluating thermal comfort conditions and health responses during an extremely hot summer in athens," Build. Environ., (2011). doi:10.1016/j.buildenv.2010.07.026.

6) A.G. Alam, Nasruddin, A. Tirta, and C.K. Priambada, "Building beneficial roof insulation in vertical housing: physical and economical selection method," Evergreen, $6 \quad$ (2) 124-133 (2019). doi:10.5109/2321006.

7) A.S. Hutomo, and A.H. Fuad, "Engagement and wellbeing in public space. case study: suropati park jakarta," Evergreen, 7 (1) 138-143 (2020). doi:10.5109/2740970.

8) N. Hamidah, R. Rijanta, B. Setiawan, and M.A. Marfai, “'Kampung' as a formal and informal integration model (case study: kampung pahandut, central kalimantan province, indonesia)," Int. J. Spat. Reg. Anal., 31 (July 2017) 43-55 (2017). doi:10.23917/forgeo.v31i1.3047.

9) S. Funo, N. Yamamoto, and J. Silas, "Typology of kampung houses and their transformation process: a study on urban tissues of indonesian city," J. Asian Arch. Build. Eng., 1 193-200 (2002).

10) S. Sastrisasmito, "Compact kampungs: formal and informal integration in the context of urban settlements of yogyakarta, indonesia," J. Habitat Eng., 1 119-134 (2009).

11) B. Sudarwanto, G. Hardiman, A. Suprapti, and A.B. Sarjono, "The uniqueness and complexity of kampung city bustaman semarang indonesia," IOP Conf. Ser. Earth Environ. Sci., 99 (1) (2018). doi:10.1088/1755-1315/99/1/012005

12) B. Setiawan, "Local dynamics in informal settlement development: a case study of Yogyakarta, Indonesia," The University of British Columbia, 1998.

13) R. Kimura, "Social or business or 'social and business': problematique of the hybrid structure of community-based ecotourism in cambodia," Evergreen, $4 \quad$ (2-3) 38-49 (2017). doi:10.5109/1929664.

14) M.H. Huzaifi, M.A. Budiyanto, and S.J. Sirait, "Study on the carbon emission evaluation in a container port based on energy consumption data," Evergreen, $7 \quad$ (1) 97-103 (2020). doi:10.5109/2740964.

15) M. Kottek, J. Grieser, C. Beck, B. Rudolf, and F. Rubel, "World map of the koppen-geiger climate classification updated," Meteorol. Zeitschrift, 15 (3) 259-263 (2006). doi:10.1127/0941-2948/2006/0130.

16) T.H. Karyono, "Predicting comfort temperature in indonesia, an initial step to reduce cooling energy consumption," Buildings, 5 (3) 802-813 (2015). doi:10.3390/buildings5030802.

17) W. Retno, and H.A. Sudibyakto, "Identifikasi urban heat island di kota surakarta," J. Bumi Indones., 6 (1) 1-9

(2017). https://media.neliti.com/media/publications/228744identifikasi-urban-heat-island-di-kota-sad3c024b.pdf.

18) BPS, "Surakarta Manucipality in Figures 2016," 2016.

19) R. Fillaili, "Addressing Urban Poverty: Increasing Learning on Urban Poverty Reduction in Kota Surakarta and Kota Makassar, Indonesia Increasing Learning on Urban Poverty Reduction,” Jakarta, 2011. https://www.smeru.or.id/sites/default/files/publicatio n/urbanpoverty_eng.pdf.

20) C.J. Government, "Keputusan gubernur jawa tengah no. 560/66," (2015). http://www.semarangkab.go.id/utama/images/stories /data/sk_umk_2016.pdf.

21) "Sangkrah mini atlas," Solo Kita Kita, 1 (2010).

22) E. Nix, C. Shrubsole, P. Das, and M. Davies, "Indoor environmental quality of low-income housing in Delhi, India: Findings from a field study," in: Energy Procedia, 2015. doi:10.1016/j.egypro.2015.11.714.

23) L. Bellahcene, A. Cheknane, S. Bekkouche, and D. Sahel, "The effect of the thermal inertia on the thermal transfer in building wall," E3S Web Conf., 22 00013 (2017). doi:10.1051/e3sconf/20172200013.

24) S. Wei, M. Li, W. Lin, and Y. Sun, "Parametric studies and evaluations of indoor thermal environment in wet season using a field survey and pmv-ppd method," Energy Build., $42 \quad$ (6) 799-806 (2010). doi:10.1016/j.enbuild.2009.11.017.

25) T. Chaudhuri, Y.C. Soh, S. Bose, L. Xie, and H. Li, "On assuming mean radiant temperature equal to air temperature during pmv-based thermal comfort study in air-conditioned buildings," IECON Proc. (Industrial Electron. Conf., 7065-7070 (2016). 
doi:10.1109/IECON.2016.7793073.

26) E. Diaz Lozano Patiño, D. Vakalis, M. Touchie, E. Tzekova, and J.A. Siegel, "Thermal comfort in multiunit social housing buildings," Build. Environ., (2018). doi:10.1016/j.buildenv.2018.08.024.

27) S.C. Turner, G. Paliaga, B.M. Lynch, E.A. Arens, R.M. Aynsley, G.S. Brager, J.J. Deringer, J.M. Ferguson, J.M. Filler, J.J. Hogeling, D. Int-hout, A.G. Kwok, H.F. Levy, E.M. Sterling, J.L. Stoops, S.T. Taylor, R.W. Tinsley, K.W. Cooper, K.W. Dean, F. Myers, and J.C. Peterson, "ASHRAE standard 552010 thermal environmental conditions for human occupancy," 201030 (2010). 